\title{
Grazing impact of two small heterotrophic flagellates on Prochlorococcus and Synechococcus
}

\author{
Laure Guillou $^{1, *}$, Stéphan Jacquet ${ }^{1, * *}$, Marie-Josèphe Chrétiennot-Dinet ${ }^{2}$, Daniel Vaulot ${ }^{1}$ \\ ${ }^{1}$ Station Biologique de Roscoff, CNRS, INSU and Université Pierre et Marie Curie, Place Georges Teissier, BP 74, 29682 Roscoff Cedex, France \\ ${ }^{2}$ Observatoire Océanologique de Banyuls, CNRS, INSU and Université Pierre et Marie Curie, BP 44, 66651 Banyuls-sur-mer, France
}

\begin{abstract}
In open oceanic waters, phytoplankton biomass is dominated by organisms below 2 to $3 \mu \mathrm{m}$ in size (pico- and small nanophytoplankton). The cell concentration of these populations is very stable in time and space as a consequence of nutrient limitation and strong grazing pressure. Although the identity of the organisms that directly graze on picoplankton is largely unknown, they are thought to be very small, i.e. $<3$ to $5 \mu \mathrm{m}$. Here, we analyze the grazing impact of 2 small flagellates, Symbiomonas scintillans and Picophagus flagellatus, upon 2 oceanic cyanobacteria, Prochlorococcus and Synechococcus. S. scintillans does not feed on the 2 cyanobacteria. In contrast, $P$. flagellatus appears as an active predator capable of drastically reducing prey concentrations. The flagellate displays a substantial division rate of the order of 2 doublings $\mathrm{d}^{-1}$ when fed on Prochlorococcus cells, but no significant growth is recorded when Synechococcus is used as prey. As the majority ( $>80 \%$ ) of $P$. flagellatus cells can pass throughout a $2 \mu \mathrm{m}$ filter, the impact of such tiny predators should be taken into consideration during field experiments that rely on size fractionation to separate grazers from prey.
\end{abstract}

KEY WORDS: Heterotrophic flagellates - Stramenopiles · Picoplankton - Picophagus flagellatus - Symbiomonas scintillans $\cdot$ Prochlorococcus $\cdot$ Synechococcus $\cdot$ Grazing

Resale or republication not permitted without written consent of the publisher

In most oligotrophic and mesotrophic areas of the world oceans, primary production is dominated by cells of $<2$ to $3 \mu \mathrm{m}$ (picophytoplankton) (Li et al. 1983, Platt et al. 1983). Picophytoplankton is composed of the 2 cyanobacteria genera Prochlorococcus (Chisholm et al. 1992) and Synechococcus (Waterbury et al. 1979) and a

Present addresses:

*Institut de Ciències del Mar, CISC Passeig Maritim de la Barceloneta 37-45, 08003 Barcelona, Spain.

E-mail: laure.guillou@icm.csic.es

${ }^{* *}$ Station INRA d'Hydrologie Lacustre, Laboratoire Dynamique et Evolution des Communautés Phytoplanctoniques, UMR CARRTEL, BP 511, 74203 Thonon Cedex, France poorly defined assemblage of eukaryotic algae (Johnson \& Sieburth 1982, Andersen et al. 1996). Despite growth rates of the order of 1 division $\mathrm{d}^{-1}$ (Liu et al. 1995, Vaulot et al. 1995), the abundance of these populations remains at nearly constant levels over time scales ranging from days to years (Campbell et al. 1997). Prochlorococcus and Synechococcus cells are too small to be consumed directly by mesozooplankton, including small copepods and cladocerans. The carbon sequestered as a result of photosynthesis moves to higher trophic levels via intermediate small grazers, mainly identified as flagellates (Sherr et al. 1986, Hagström et al. 1988). Size fractionation experiments have revealed that the first level of grazers is significantly smaller than $5 \mu \mathrm{m}$ (typically below 2 to $3 \mu \mathrm{m}$ in diameter) in coastal waters (Wikner \& Hagström 1988), in the upper water column of the Arctic Ocean (Sherr et al. 1997), and in more oligotrophic ecosystems, such as the Mediterranean Sea (Zohary \& Robarts 1992), the Sargasso Sea (Caron et al. 1999), and the Arabian Sea (Reckerman \& Veldhuis 1997). Nevertheless, most of these tiny oceanic planktonic predators remain unidentified.

During an oceanographic cruise conducted in the equatorial Pacific Ocean (OLIPAC, November 1994), we made systematic isolations to investigate picoplanktonic diversity. Surprisingly, without any addition of organic matter, 2 different heterotrophic flagellates of very small size $(<4 \mu \mathrm{m})$ were isolated from surface waters in the transition zone separating the oligotrophic gyre from the equatorial upwelling (Guillou et al. 1999a). Because very little is known about the potential grazing activity of such small flagellates on picoplanktonic populations, we conducted laboratory experiments to examine the consumption by Picophagus flagellatus and Symbiomonas scintillans of the 2 widespread very small marine cyanobacteria Prochlorococcus $(0.6 \mu \mathrm{m})$ and Synechococcus $(1.0 \mu \mathrm{m})$. 
Materials and methods. Picophagus flagellatus (Chrysophyceae, RCC 22, RCC = Roscoff Culture Collection, Station Biologique de Roscoff, France, see www.sb-roscoff.fr/Phyto/collect.html for more information) and Symbiomonas scintillans (Bicosoecida, RCC 24) were initially isolated in K medium (Keller et al. 1987) by serial dilution from equatorial Pacific waters $\left(150^{\circ} \mathrm{W}, 11^{\circ} 50^{\prime} \mathrm{S}, 15 \mathrm{~m}\right.$ depth). One month before the grazing experiments, cultures of $P$. flagellatus and $S$. scintillans were acclimated to the culture conditions of Prochlorococcus SS 120 (CCMP 1375, CCMP = Culture Center for Marine Phytoplankton, Bigelow Laboratory for Ocean Sciences, West Boothbay Harbor, ME) and Synechococcus WH 8103 in PCRS11 medium (Rippka et al. 2000), at $19^{\circ} \mathrm{C}$ with $15 \mu \mathrm{mol}$ quanta $\mathrm{m}^{-2} \mathrm{~s}^{-1}$ of continuous blue light provided by cool-white fluorescent bulbs wrapped in a blue filter (Lee filter, Panavision, France). Thin sections were prepared as in Guillou et al. (1999a).

Long- and short-term experiments were conducted using the same controls and experiment flasks. Controls were prepared by mixing different solutions of $0.2 \mu \mathrm{m}$-filtered medium from Prochlorococcus (Pro) (C1), Synechococcus (Syn) (C2), and predator (C3) cultures: (1) $50 \mathrm{ml}$ of Pro culture $+150 \mathrm{ml}$ of $\mathrm{C} 3$; (2) $50 \mathrm{ml}$ of Syn culture $+150 \mathrm{ml}$ of C3; (3) Pro and Syn, $25 \mathrm{ml}$ of each prey cultures $+150 \mathrm{ml}$ of C3; (4) $150 \mathrm{ml}$ of predator culture $+25 \mathrm{ml}$ of both $\mathrm{C} 1$ and $\mathrm{C} 2$. The other flasks received $150 \mathrm{ml}$ of predator culture and $50 \mathrm{ml}$ of prey cultures ([5] Pro + predator; [6] Syn + predator; [7] Pro + Syn + predator). First, we performed long-term experiments (6 d) during which we analyzed the grazing behavior and growth response of a given diet, i.e. Prochlorococcus and Synechococcus using exponentially growing prey. Second, we determined grazing parameters (grazing, clearance and ingestion rates, and specific clearance, see below) from short-term experiments $(10 \mathrm{~h})$ to minimize changes in grazer concentration on the estimated parameter. The concentration of the prey (Synechococcus and Prochlorococcus) and Picophagus flagellatus were followed by sampling $1 \mathrm{ml}$ every $2.5 \mathrm{~h}$. Prey concentrations were adjusted to 2 and $7 \times 10^{5}$ cell $\mathrm{ml}^{-1}$ for Synechococcus and Prochlorococcus respectively, in order to mimic the highest concentrations found in oceanic waters. The concentration of $P$. flagellatus was adjusted to be 1 order of magnitude lower than that of the prey.

During these experiments, $1 \mathrm{ml}$ was sampled from each treatment several times a day. Concentrations were determined in triplicates using flow cytometry (FCM, FACSort, Becton Dickinson, CA) after appropriate dilution using $0.2 \mu \mathrm{m}$-filtered seawater to avoid FCM coincidence. Because the cultures were nonaxenic, we also monitored the concentration of hetero- trophic bacteria. Heterotrophic bacteria and heterotrophic flagellates were counted after staining of intracellular nucleic acids by the SYBR Green I dye (Molecular Probes, Eugene, OR) according to Marie et al. (2000). When possible, the heterotrophic flagellates were also detected from the autofluorescence of their ingested prey. All parameters were normalized with $0.95 \mu \mathrm{m}$-calibrated beads. Data were collected as list mode files (i.e. parameter values were stored for each cell) and analyzed using the CYTOWIN software (Vaulot 1989; available at www.sb-roscoff.fr/Phyto/ cyto.html). Growth and grazing parameters were calculated using the equations established by Frost (1972) and Heinbokel (1978) and revised by Marin and coworkers (1986), as summarized below:

Net growth rate, $\mu\left(\mathrm{d}^{-1}\right)$, of the preys in the control flasks and of the predator in all flasks during long-term experiments was estimated as

$$
\mu=\frac{\ln C\left(t_{2}\right)-\ln C\left(t_{1}\right)}{t_{2}-t_{1}}
$$

where $C(t)$ is the concentration (cell ml-1) of the prey or of the predator at time $t(\mathrm{~d})$ and $t_{1}$ and $t_{2}$ correspond to the time at the beginning and the end of the experiment respectively.

Grazing rate, $g\left(\mathrm{~d}^{-1}\right)$, was computed for the shortterm experiment as

$$
g=\frac{\ln C\left(t_{1}\right)-\ln C\left(t_{2}\right)}{t_{2}-t_{1}}
$$

where $C(t)$ is the concentration of the prey (cell ml-1) mixed with the grazer (this equation assumes that the growth rate of the prey is close to zero) and $t_{2}-t_{1}$ is the total duration of the experiment $(10 \mathrm{~h})$.

Clearance rate, $F\left(\mathrm{ml} \mathrm{cell}{ }^{-1} \mathrm{~h}^{-1}\right)$, was computed for the short-term experiment as

$$
F=\frac{g}{24 \times \bar{C}_{\mathrm{g}}}
$$

where $\bar{C}_{\mathrm{g}}$ is the mean concentration of the grazer (cell $\mathrm{ml}^{-1}$ ) during the experiment.

Ingestion rate, IR ([cells eaten] flagellate $\mathrm{f}^{-1} \mathrm{~h}^{-1}$ ), was computed during the short-term experiment as

$$
I R=F \times \bar{C}_{\mathrm{p}}
$$

where $\bar{C}_{\mathrm{p}}$ is the mean concentration of the prey (cell $\left.\mathrm{ml}^{-1}\right)$.

Specific clearance, $S C\left(\mathrm{ml} \mathrm{cell} \mathrm{H}^{-1} \mathrm{~m}^{-3} \mathrm{~h}^{-1}\right)$, was computed during the short-term experiment as

$$
S C=\frac{F}{V_{\mathrm{g}}}
$$

where $V_{\mathrm{g}}$ is the biovolume of grazer $\left(\mathrm{m}^{3}\right)$.

The carbon conversion factors $(B)$ used in this study were $250 \mathrm{fg} \mathrm{C} \mathrm{cell}^{-1}$ for Synechococcus (Kana \& Glibert 
1987), $50 \mathrm{fg} \mathrm{C}^{\mathrm{C}} \mathrm{cell}^{-1}$ for Prochlorococcus (Cailliau et al.

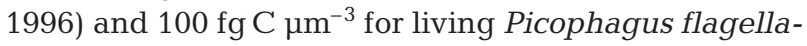
tus (Bфrsheim \& Bratbak 1987). Because the previous size description of $P$. flagellatus was based upon fixed cells (Guillou et al. 1999a), we measured the size of living cells by optical microscopy (Olympus Fluoview) calibrated using a micrometer. P. flagellatus was found to have a mean width of $2.2 \mu \mathrm{m}$ and a mean length of $3.2 \mu \mathrm{m}$. With a cell volume of $8.1{\mu \mathrm{m}^{3}}^{3}$, as calculated from the volume of an ellipsoid, the carbon content of $P$. flagellatus was thus estimated to be $810 \mathrm{fg} \mathrm{C} \mathrm{cell}^{-1}$.

Carbon transfer efficiency (CE) was computed during the long-term experiment as

$$
C E=\frac{\left(C_{\mathrm{g}^{\prime}}-C_{\mathrm{g}}\right) \times B_{\mathrm{g}}}{\left(C_{\mathrm{p}}-C_{\mathrm{p}^{\prime}}\right) \times B_{\mathrm{p}}}
$$

where $C_{\mathrm{g}^{\prime}}$ is the final concentration of the grazer mixed with the prey, $C_{g}$ the final concentration of the grazer in the control flasks (without prey), $C_{\mathrm{p}}$ the final prey concentration in the control flasks (without grazer), $C_{\mathrm{p}^{\prime}}$ the final concentration of the prey mixed with the grazer (cell ml-1), and $B_{\mathrm{g}}$ and $B_{\mathrm{p}}$ the carbon biomass ( $\mathrm{fgC} \mathrm{Cell}^{-1}$ ) of the grazer and prey, respectively, estimated as detailed above.

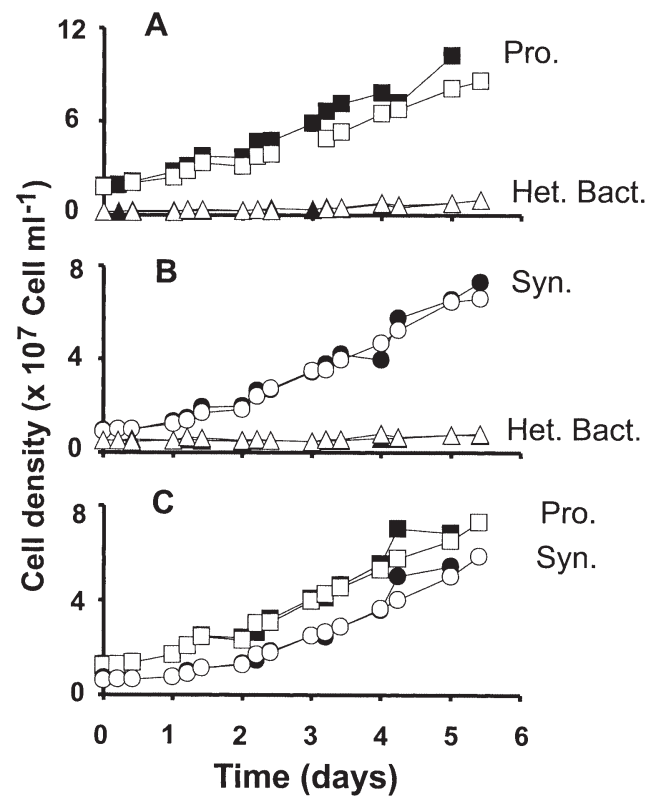

Fig. 1. Time-course changes in cell concentrations of Prochlorococcus ( $\mathbf{\square}$, Pro), Synechococcus $(\bullet$, Syn), and heterotrophic bacteria ( $\boldsymbol{\Lambda}$, Het bact), during long-term experiments using Symbiomonas scintillans. Solid symbols: control cultures without heterotrophic flagellates; open symbols: autotrophic cultures mixed with the corresponding heterotrophic flagellates. (A-C) Changes in cell concentration of (A) Prochloroccocus, (B) Synechococcus, (C) mixed culture of Prochlorococcus + Synechococcus and (A,B) heterotrophic bacteria. Concentrations were determined in triplicates, counting error bars were always smaller than the data points
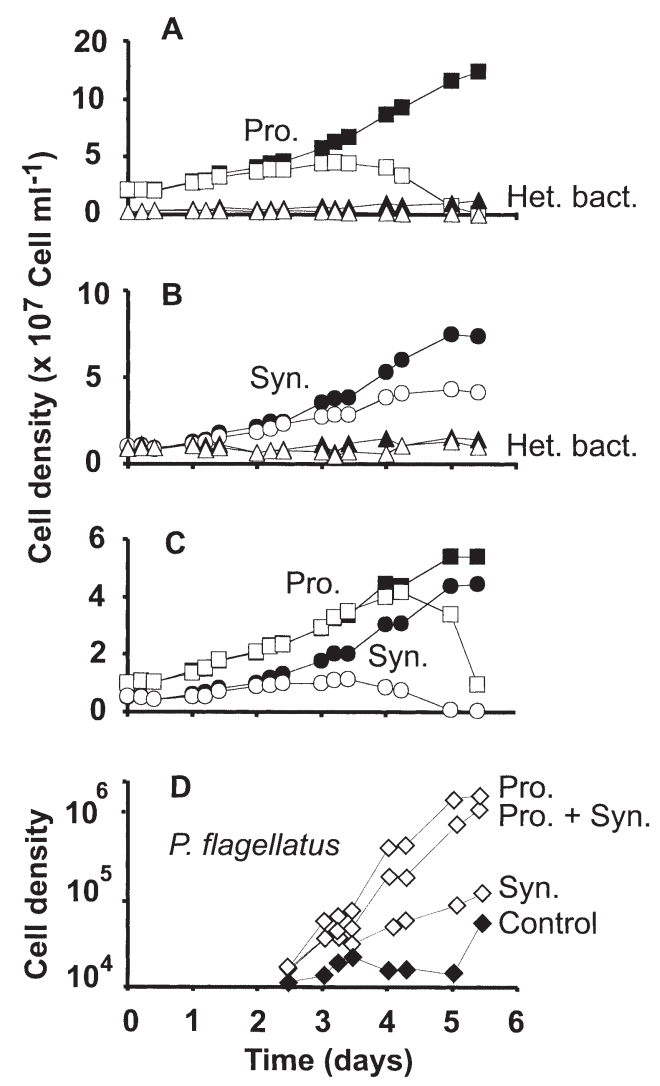

Fig. 2. Time-course changes in cell concentration of Prochlorococcus $(\mathbf{\square}$, Pro), Synechococcus $(\bullet$, Syn), and heterotrophic bacteria ( $\boldsymbol{\Lambda}$, Het bact), during long-term experiments using Picophagus flagellatus $(\diamond)$. Solid symbols: control cultures without heterotrophic flagellates; open symbols: autotrophic cultures mixed with the corresponding heterotrophic flagellates. (A-C) Changes in the cell concentration of (A) Prochloroccocus, (B) Synechococcus, and (C) mixed culture of Prochlorococcus + Synechococcus. (D) Change in the cell concentration (log scale) of $P$. flagellatus alone or mixed with prey. Heterotrophic bacteria are also presented in flasks

containing Prochlorococcus (A) and Synechococcus (B)

Results. No clear differences in cell numbers were observed between the control flasks and the different cultures mixed with Symbiomonas scintillans (Fig. 1). We were not able to count the flagellate by flow cytometry when it was mixed with autotrophic prey because of its relative low concentration and the overlapping of its signature by flow cytometry with those of heterotrophic bacteria.

In contrast, grazing of Picophagus flagellatus on Prochlorococcus and Synechococcus was clearly observed (Fig. 2) after $2 \mathrm{~d}$ of incubation. The predator cell number increased from $10^{4}$ cells $\mathrm{ml}^{-1}$ initially to $10^{6}$ cells $\mathrm{ml}^{-1}$ after 4 d. P. flagellatus fed on Prochlorococcus drastically reduced the prey population (the final Prochlorococcus concentration in the control flask was $1.2 \times 10^{8}$ cells ml ${ }^{-1}$ vs $5.8 \times 10^{5}$ cells ml $^{-1}$ in the flask mixed with $P$. flagellatus, see Table 1 ). The maximal 
Table 1. Long-term experiments (6 d). Growth rates and concentrations of Picophagus flagellatus feeding on Prochlorococcus (Pro), Synechococcus (Syn) and mixed cultures of Prochlorococcus and Synechococcus (Pro + Syn)

\begin{tabular}{|c|c|c|c|c|}
\hline & Pro & Syn & \multicolumn{2}{|c|}{ Pro + Syn } \\
\hline \multicolumn{5}{|l|}{ Picophagus flagellatus } \\
\hline Maximum growth rate $\left(\mathrm{d}^{-1}\right)$ & 1.6 & 0.6 & \multirow{2}{*}{\multicolumn{2}{|c|}{$\begin{array}{c}1.5 \\
10^{4} \pm 2 \times 10^{3}\end{array}$}} \\
\hline $\begin{array}{l}\text { Initial } P \text {. flagellatus concentration } \\
\left(\text { cells } \mathrm{ml}^{-1}\right) \pm \mathrm{SD}\end{array}$ & $10^{4} \pm 2 \times 10^{3}$ & $10^{4} \pm 2 \times 10^{3}$ & & \\
\hline $\begin{array}{l}\text { Final } P \text {. flagellatus concentration in } \\
\text { flasks mixed with prey }\left(\text { cells } \mathrm{ml}^{-1}\right) \pm \mathrm{SD}\end{array}$ & $1.7 \times 10^{6} \pm 2 \times 10^{5}$ & $10^{5} \pm 8 \times 10^{3}$ & \multicolumn{2}{|c|}{$1.1 \times 10^{6} \pm 3 \times 10^{5}$} \\
\hline $\begin{array}{l}\text { Increase in flagellate carbon }\left(\mathrm{fg} \mathrm{C} \mathrm{ml}^{-1} \text { ) }\right. \\
\text { in flasks mixed with prey }\end{array}$ & $1.36 \times 10^{9}$ & $7.29 \times 10^{7}$ & \multicolumn{2}{|c|}{$8.83 \times 10^{8}$} \\
\hline \multicolumn{5}{|l|}{ Cyanobacteria prey } \\
\hline Growth rate $\left(\mathrm{d}^{-1}\right)$ estimated from control flasks & 0.3 & 0.3 & 0.24 & 0.38 \\
\hline Initial prey concentration $\left(\right.$ cells ml $\left.{ }^{-1}\right) \pm \mathrm{SD}$ & $2 \times 10^{7} \pm 5 \times 10^{5}$ & $1 \times 10^{7} \pm 1 \times 10^{5}$ & $1 \times 10^{7} \pm 8 \times 10^{4}$ & $5 \times 10^{6} \pm 6 \times 10^{4}$ \\
\hline $\begin{array}{l}\text { Final prey concentration in control flasks } \\
\left(\text { cells } \mathrm{ml}^{-1}\right) \pm \mathrm{SD}\end{array}$ & $1.2 \times 10^{8} \pm 2 \times 10^{6}$ & $7.3 \times 10^{7} \pm 3 \times 10^{6}$ & $5.4 \times 10^{7} \pm 7 \times 10^{5}$ & $4.5 \times 10^{7} \pm 1 \times 10^{5}$ \\
\hline $\begin{array}{l}\text { Final prey concentration in flasks mixed } \\
\left.\text { with } P \text {. flagellatus (cells } \mathrm{ml}^{-1}\right) \pm \mathrm{SD}\end{array}$ & $5.8 \times 10^{5} \pm 6 \times 10^{3}$ & $4 \times 10^{7} \pm 6 \times 10^{5}$ & $1 \times 10^{6} \pm 5 \times 10^{5}$ & $3 \times 10^{5} \pm 6 \times 10^{3}$ \\
\hline 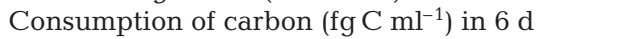 & $5.9 \times 10^{9}$ & $8.2 \times 10^{9}$ & $2.6 \times 10^{9}$ & $1.1 \times 10^{10}$ \\
\hline Carbon transfer efficiency $(\%)$ & 23 & 0.9 & & 6 \\
\hline
\end{tabular}

growth rate of $P$. flagellatus feeding on Prochlorococcus was larger than 2 doublings $\mathrm{d}^{-1}\left(\mu=1.6 \mathrm{~d}^{-1}\right.$, Table 1), and the concentration of the predator reached a final density of $1.7 \times 10^{6}$ cells ml $\mathrm{m}^{-1}$ (Table 1 ). The use of Synechococcus as a prey induced significantly less efficient prey removal (Fig. 2B) as well as a lower maximum growth rate $\left(\mu=0.6 \mathrm{~d}^{-1}\right.$, Table 1$)$ and a lower final concentration $\left(10^{5}\right.$ cells $\mathrm{ml}^{-1}$, Table 1$)$ for $P$. flagellatus. When $P$. flagellatus was fed with the 2 photosynthetic prey given together, it grazed on them and drastically reduced both of them (Fig. 2C), although its growth rate and final cell numbers were lower than when it was fed on Prochlorococcus alone (Table 1). It is noteworthy that, at a similar prey concentration, P. flagellatus grazed first on Synechococcus rather than on Prochlorococcus. However, when Prochorococcus became about 3 times more concentrated than Synechococcus, it began to be eaten as well. In terms of carbon transfer efficiency, Synechococcus is a very poor food (less than 1\% when offered alone). Comparatively, Prochlorococcus contributed to $23 \%$ of the carbon transfer efficiency (Table 1). At the end of the experiment, we observed that the side scatter (SSC) parameter of $P$. flagellatus, a proxy for cell size, was much higher when it was fed on Synechococcus (SSC = 2.2 relative to $0.95 \mu \mathrm{m}$ beads) than on Prochlorococcus $(\mathrm{SSC}=1.45)$ or on a mixture of the prey $(\mathrm{SSC}=1.5)$. Microscopic observations also revealed that P. flagellatus lost its motility when fed on Synechococcus alone. Heterotrophic bacteria were also present, since the cultures were not axenic. At the beginning of the longterm experiment, their concentration was 10 times lower than Prochlorococcus and similar to that of the cyanobacteria in the other cases. However, in all experiments, they only represented a minor fraction of the consumed prey (Fig. 2A,B).

The concentration of Picophagus flagellatus did not change significantly during the short-term experiment $(10 \mathrm{~h})$ and remained around $2.5 \times 10^{4}$ cell ml $\mathrm{m}^{-1}$ in all flasks. Under these conditions, a reduction in both Prochlorococcus and Synechococcus cells was evident after $2.5 \mathrm{~h}$ of incubation (Fig. 3). Clearance rates of $P$. flagellatus were estimated to be $2.3 \mathrm{nl} \mathrm{cell}^{-1} \mathrm{~h}^{-1}$ for Prochlorococcus and $2.5 \mathrm{nl} \mathrm{cell}{ }^{-1} \mathrm{~h}^{-1}$ for Synechococcus (Table 2). When the 2 prey were mixed together, the clearance rate for Synechococcus was more than twice as high as that for Prochlorococcus (Table 2). The clearance rate for Synechococcus was also higher when it was mixed with Prochlorococcus (3.8 $\mathrm{nl} \mathrm{cell}^{-1}$ $\mathrm{h}^{-1}$ ) than when it was offered alone $\left(2.5 \mathrm{nl} \mathrm{cell}^{-1} \mathrm{~h}^{-1}\right)$. Since in this study we used the highest prey concentration found in natural samples, our estimates of clearance rates are probably on the low side. Ingestion rate was higher with Prochlorococcus alone than with Synechococcus alone or mixed with Prochlorococcus (Table 2). Based on our calculations, an individual P. flagellatus ate an average of 1 Prochlorococcus $\mathrm{h}^{-1}$. Based on electron microscopy sections, an individual $P$. flagellatus could indeed contain 1 or 2 entire or partly digested prey (Fig. 4).

Discussion. Picophagus flagellatus and Symbiomonas scintillans belong to the Stramenopiles (Guillou et al. 1999a). This lineage is known to include several active phagotrophic species such as Paraphysomonas spp. (Chrysophyceae) and Cafeteria spp. (Bicosoecida). A number of features suggested phagotrophy in 


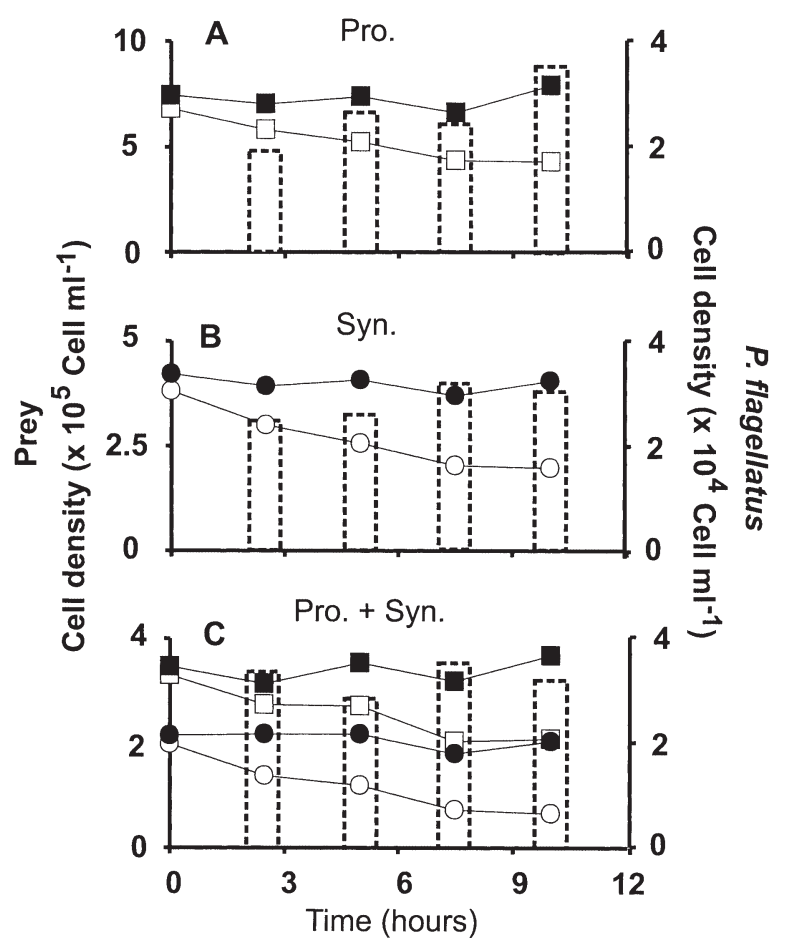

Fig. 3. Time-course changes in cell concentration of Prochlorococcus (ם, Pro) and Synechococcus (•, Syn) during short-term experiments using Picophagus flagellatus. Prey (left scale): (A) Prochlorococcus, (B) Synechococcus, and (C) mixed culture of Prochlorococcus and Synechococcus. Bars (right scale) represent $P$. flagellatus concentration in the mixed culture

P. flagellatus and S. scintillans. Indeed, both of them bear a hairy flagellum and a complex microtubule network (Guillou et al. 1999a), which are known to help in prey capture (Andersen \& Wetherbee 1992). The long hairy flagellum of $P$. flagellatus is very spectacular in this context (over 6 times the cell diameter). Typically, half of the cellular volume of $P$. flagellatus is filled with large phagotrophic vesicles that sometimes contain recognizable bacteria, demonstrating that this flagellate feeds on free-living heterotrophic bacteria present in the cultures (as they are not axenic). Several micro-

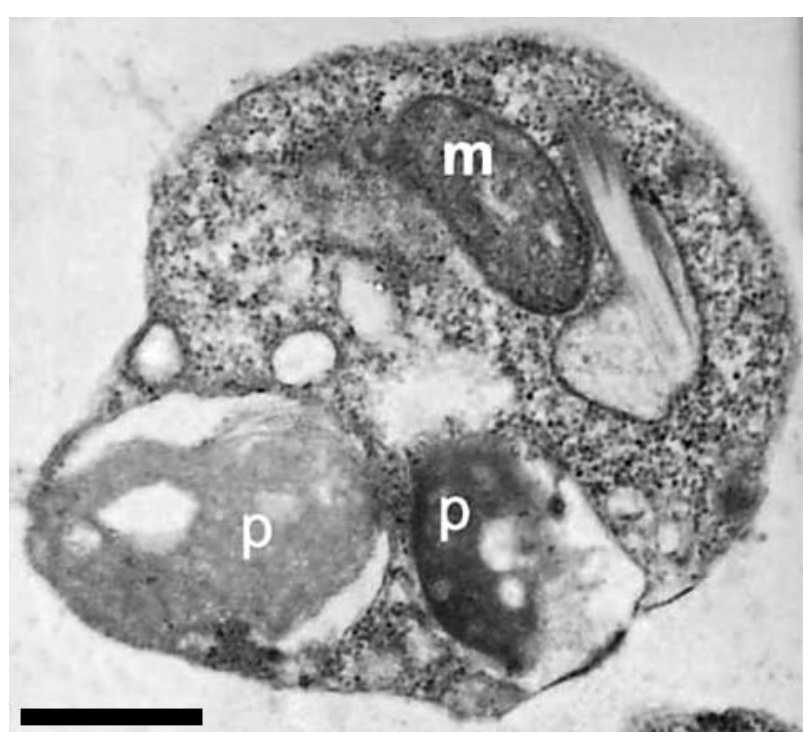

Fig. 4. Thin section of Picophagus flagellatus feeding with Prochlorococcus observed in transmission electron microscopy. A mitochondrion (m) and 2 food vesicle containing partially digested Prochlorococcus (p) are visible. Scale bar $=$ $500 \mathrm{~nm}$

graphs also revealed the phagotrophic capacities of $S$. scintillans (see Fig. 1D from Guillou et al. 1999a). This latter species is characterized by the presence of several endosymbiotic bacteria located close to the nucleus (Guillou et al. 1999a). Although this species can apparently be phagotrophic (Guillou et al. 1999a), it does not appear to be an active predator of either Synechococcus or Prochlorococcus or of the free-living heterotrophic bacteria contained in our cultures. This suggests that $S$. scintillans may feed on other prey, such as smaller heterotrophic bacteria typically found in marine waters, but it may also feed by osmotrophy. In this context, the trophic role of $S$. scintillans endosymbiotic bacteria deserves further scrutiny.

In contrast, Picophagus flagellatus is an active predator of both Prochlorococcus and Synechococcus. At a similar prey concentration, Synechococcus is

Table 2. Short-term experiments $(10 \mathrm{~h})$. Growth and grazing parameters measured for Picophagus flagellatus feeding on Prochlorococcus (Pro), Synechococcus (Syn) and on mixed cultures of Prochlorococcus and Synechococcus (Pro + Syn)

\begin{tabular}{|c|c|c|c|c|}
\hline Grazing parameters & Pro & Syn & \multicolumn{2}{|c|}{ Pro + Syn } \\
\hline Prey growth rate $\left(\mathrm{h}^{-1}\right)$ determined in controls & 0.0056 & -0.0046 & 0.0058 & -0.0057 \\
\hline Grazing rate $\left(\mathrm{h}^{-1}\right)$ & 0.052 & 0.061 & 0.045 & 0.107 \\
\hline Mean grazer concentration $\left(\right.$ cells ml $\left.{ }^{-1}\right) \pm \mathrm{SD}$ & $2.3 \times 10^{4} \pm 6 \times 10^{3}$ & $2.4 \times 10^{4} \pm 3 \times 10^{3}$ & \multicolumn{2}{|c|}{$2.8 \times 10^{4} \pm 3 \times 10^{3}$} \\
\hline Mean prey concentration (cells ml $\left.{ }^{-1}\right) \pm \mathrm{SD}$ & $5.2 \times 10^{5} \pm 1 \times 10^{5}$ & $2.7 \times 10^{5} \pm 8 \times 10^{4}$ & $2.6 \times 10^{5} \pm 5 \times 10^{4}$ & $1.2 \times 10^{5} \pm 5 \times 10^{4}$ \\
\hline Clearance rate $\left(10^{-6} \mathrm{ml} \mathrm{cell}^{-1} \mathrm{~h}^{-1}\right)$ & 2.3 & 2.5 & 1.6 & 3.8 \\
\hline Ingestion ([cells eaten] flagellate ${ }^{-1} \mathrm{~h}^{-1}$ ) & 1.2 & 0.7 & 0.4 & 0.4 \\
\hline Specific clearance $\left(10^{4} \mathrm{ml} \mathrm{cell}^{-1} \mathrm{~m}^{-3} \mathrm{~h}^{-1}\right)$ & 28 & 30 & 19 & 47 \\
\hline
\end{tabular}


grazed in preference to Prochlorococcus or heterotrophic bacteria. The clearance rates of $P$. flagellatus fall into the lower range reported for larger heterotrophic nano-flagellates both in cultures (mainly based on Paraphysomonas spp.) and in the field, i.e. 0.5 to $27 \mathrm{nl}$ flagellate ${ }^{-1} \mathrm{~h}^{-1}$ for Synechococcus (Christoffersen 1994, Dolan \& Šimek 1999) or 4 to 24 nl flagellate ${ }^{-1} \mathrm{~h}^{-1}$ for Prochlorococcus (Monger et al. 1999). However, it should be noted that our estimates are derived from experiments using very high prey concentrations. The specific clearance rate is higher for Synechococcus than for Prochlorococcus, and 10 to $100 \times$ higher than that calculated for ciliates (Christaki et al. 1999). However, Synechococcus is not efficiently assimilated, as is suggested by the very low carbon transfer efficiency we found. The $P$. flagellatus volume increases observed at the end of the long-term experiment could be due to the fact that Synechococcus cells are not digested. This poor digestibility of Synechococcus has been observed recently in appendicularians (Gorsky et al. 1999). Similarly, Caron et al. (1991) reported that protozoa displayed faster growth rates and higher cell yields on heterotrophic bacteria than on Synechococcus. In contrast, Synechococcus is efficiently consumed by some ciliates, such as Strombidium sulcatum (Christaki et al. 1999).

Using the particle-size model of Sheldon et al. (1972), Azam et al. (1983) suggested that in marine food chains the optimum size difference between a predator and its prey is about 1 order of magnitude in length (or $10^{3}$ in volume) with a carbon transfer efficiency of $10 \%$ between each compartment. For microbial food webs, it is widely accepted that this predator:prey size ratio is smaller (Goldman \& Caron 1985, Hansen et al. 1994). The current paradigm is that 0.4 to $1 \mu \mathrm{m}$ bacteria are grazed by $5 \mu \mathrm{m}$ nanoflagellates, themselves being grazed by 10 to $20 \mu \mathrm{m}$ nanozooplankton or larger ciliates. If we consider a predator:prey size ratio of $3: 1$ and a 2 to $4 \mu \mathrm{m}$ size for Picophagus flagellatus, this species can potentially graze all prey smaller than $1.3 \mu \mathrm{m}$ in diameter. Of the cells of $P$. flagellatus, $87 \%$ pass through a $2 \mu \mathrm{m}$ filter. Therefore, field experiments based upon size fractionation should take into account that the $<2$ to $3 \mu \mathrm{m}$ fraction is not potentially free of efficient heterotrophic predators.

The existence of Picophagus flagellatus and Symbiomonas scintillans clearly demonstrates that the microbial food web may possess numerous additional steps and that the transfer efficiency of matter and energy to the higher trophic levels (i.e. to zooplankton such as copepods) is probably lower than previously hypothesized. In fact, the recent discovery of lineages based on the description of picoplanktonic species (Andersen et al. 1993, Guillou et al. 1999b) illustrates our very scant knowledge of the taxonomy of this size class. Cultured heterotrophic flagellates with sizes of less than 3 to $4 \mu \mathrm{m}$ are restricted to date to the Stramenopile lineage. Recent molecular studies, based on the cloning and the sequencing of the small subunit ribosomal RNA gene, of the picoplankton fraction obtained from the euphotic zone in the equatorial Pacific Ocean (Moonvan der Staay et al. 2001) and from the deep aphotic zone in the Antarctic Polar Front (López-García et al. 2001) have provided evidence that cells passing through a $3 \mu \mathrm{m}$ filter also contain 2 groups of previously unknown alveolates, which are very likely heterotrophic or parasitic given their close phylogenetic relatives. Clearly, this predator size class is much more taxonomically diverse than was previously thought. Their behavior and food preference are probably also very diverse, as exemplified by the difference in grazing behavior between $P$. flagellatus and S. scintillans. The next step will be to quantify their relative abundance in the field and to evaluate their role in carbon export towards the higher trophic levels. Detailed studies of the relationships between prey and predators are also necessary to better understand the structure and function of oceanic communities and to develop more accurate models of microbial food webs.

Acknowledgements. We thank J.-F. Lennon, J. Sourimant and S. Boulben for their technical assistance and S. Loiseaux-de Goër and Célia Marassé for their improvements of the manuscript. L.G. was supported by an EU grant (EVKE-CT-19995004) and by the following programs: JGOFS-France (EPOPE and PROSOPE), Réseau Biodiversité Marine, ACC-SV No. 7 and the EU programs PROMOLEC (MAS3-CT9760128) and PICODIV (EVK3-CT-1999-00021).

\section{LITERATURE CITED}

Andersen RA, Wetherbee R (1992) Microtubules of the flagellar apparatus are active during prey capture in the Chrysophycean alga Epipyxis pulchra. Protoplasma 166:8-20

Andersen RA, Saunders GW, Paskind MP, Sexton J (1993) Ultrastructure and 18S rDNA gene sequences for Pelagomonas calceolata gen. and sp. nov. and the description of a new algal class, the Pelagophyceae classis nov. J Phycol 29:701-715

Andersen RA, Bidigare RR, Keller MD, Latasa M (1996) A comparison of HPLC pigment analysis and electron microscopic observations for oligotrophic waters of the North Atlantic and Pacific Oceans. Deep-Sea Res II 43:517-537

Azam F, Fenchel T, Field JG, Gray JS, Meyer-Reil LA, Thingstad $F$ (1983) The ecological role of water-column microbes in the sea. Mar Ecol Prog Ser 10:257-263

Borsheim KY, Bratbak G (1987) Cell volume to cell carbon conversion factors for a bactivorous Monas sp. enriched from seawater. Mar Ecol Prog Ser 36:171-175

Cailliau C, Claustre H, Vidussi F, Marie D, Vaulot D (1996) Carbon biomass, and gross growth rates as estimated from ${ }^{14} \mathrm{C}$ pigment labelling method during photoacclimatation in Prochlorococcus CCMP1378. Mar Ecol Prog Ser 145: 209-221

Campbell L, Nolla HA, Vaulot D (1997) Annual variability of 
phytoplankton and bacteria in the subtropical North Pacific Ocean at station ALOHA during the 1991-1994 ENSO event. Deep-Sea Res I 44:167-192

Caron DA, Lim EL, Miceli G, Waterbury JB, Valois FW (1991) Grazing and utilization of chroococcoid cyanobacteria and heterotrophic bacteria by protozoa in laboratory cultures and a coastal plankton community. Mar Ecol Prog Ser 76: 205-217

Caron DA, Peele ER, Lim EL, Dennett MR (1999) Picoplankton and nanoplankton and their trophic coupling in surface waters of the Sargasso Sea South of Bermuda. Limnol Oceanogr 44:259-272

Chisholm SW, Frankel SF, Goericke R, Olson RJ, Palenik B, Waterbury JB, West-Johnsrud L, Zettler ER (1992) Prochlorococcus marinus nov. gen. nov. sp.: an oxyphototrophic marine prokaryote containing divinyl chlorophyll $a$ and $b$. Arch Microbiol 157:297-300

Christaki U, Jacquet S, Dolan JR, Vaulot D, Rassoulzadegan F (1999) Growth and grazing on Prochlorococcus and Synechococcus by two marine ciliates. Limnol Oceanogr 44: $52-61$

Christoffersen K (1994) Variations of feeding activities of heterotrophic nanoflagellates on picoplankton. Mar Microb Food Webs 8:111-123

Dolan JR, Šimek K (1999) Diel periodicity in Synechococcus and grazing by heterotrophic nanoflagellates: analysis of food vacuole contents. Limnol Oceanogr 44:1565-1570

Frost BW (1972) Effects of size and concentration of food particles on the feeding behavior of the marine planktonic copepod Calanus pacificus. Limnol Oceanogr 17:805-815

Goldman JC, Caron DA (1985) Experimental studies on an omnivorous microflagellate: implications for grazing and nutrient regeneration in the marine microbial food chain. Deep-Sea Res 32:899-915

Gorsky G, Chrétiennot-Dinet MJ, Blanchot J, Palazzoli I (1999) Picoplankton and nanoplankton aggregation by appendicularians: fecal pellet contents of Megalocercus huxleyi in the equatorial Pacific. J Geophys Res 104: 3381-3390

Guillou L, Chrétiennot-Dinet MJ, Boulben S, Moon-van der Staay SY, Vaulot D (1999a) Symbiomonas scintillans gen. et sp. nov. and Picophagus flagellatus gen. et sp. nov. (Heterokonta): two new heterotrophic flagellates of picoplanktonic size. Protist 150:383-398

Guillou L, Chrétiennot-Dinet MJ, Medlin LK, Claustre H, Loiseaux-de Goër S, Vaulot D (1999b) Bolidomonas: a new genus with two species belonging to a new algal class, the Bolidophyceae (Heterokonta). J Phycol 35:368-381

Hagström A, Azam F, Andersson A, Wikner J, Rassoulzadegan F (1988) Microbial loop in an oligotrophic pelagic marine ecosystem: possible roles of cyanobacteria and nanoflagellates in the organic fluxes. Mar Ecol Prog Ser 49:171-178

Hansen B, Bj申rnsen PK, Hansen PJ (1994) The size ratio between planktonic predators and their prey. Limnol Oceanogr 39:395-403

Heinbokel JF (1978) Studies on the functional role of tintinnids in the Southern California Bight. I. Grazing and growth rates in laboratory cultures. Mar Biol 47:177-189

Johnson PW, Sieburth JMcN (1982) In situ morphology and occurrence of eucaryotic phototrophs of bacterial size in the picoplankton of estuarine and oceanic waters. J Phycol 18:318-327

Kana TM, Glibert PM (1987) Effect of irradiances up to $2000 \mu \mathrm{E} \mathrm{m} \mathrm{m}^{-2} \mathrm{~s}^{-1}$ on marine Synechococcus WH7803-I. Growth, pigmentation, and cell composition. Deep-Sea
Res 34:479-495

Keller MD, Selvin RC, Claus W, Guillard RRL (1987) Media for the culture of oceanic ultraphytoplankton. J Phycol 23: 633-638

Li WKW, Subba Rao DV, Harrison WG, Smith JC, Cullen JJ, Irwin B, Platt T (1983) Autotrophic picoplankton in the tropical ocean. Science 219:292-295

Liu H, Campbell L, Landry MR (1995) Growth and mortality rates of Prochlorococcus and Synechococcus measured with a selective inhibitor technique. Mar Ecol Prog Ser 116:277-287

López-García P, Rodríguez-Valera F, Pedrós-Alío C, Moreira D (2001) Unexpected diversity of small eukaryotes in deep-sea Antarctic plankton. Nature 409:603-607

Marie D, Simon N, Guillou L, Partensky F, Vaulot D (2000) DNA/RNA analysis of phytoplankton by flow cytometry. In: Robinson JP, Darzynkiewicz Z, Dean PN, Orfao A, Rabinovitch PS, Stewart CC, Tanke HJ, Wheeless LL (eds) Current protocols in cytometry, Chapter 11.12. New York, John Wiley \& Sons, Inc, p 1-18

Marin V, Huntley ME, Frost B (1986) Measuring feeding rates of pelagic herbivores: analysis of experimental design and methods. Mar Biol 93:49-58

Monger BC, Landry MR, Brown SL (1999) Feeding selection of heterotrophic marine nanoflagellates based on the surface hydrophobicity of their picoplankton prey. Limnol Oceanogr 44:1917-1927

Moon-van der Staay SY, Wachter RD, Vaulot D (2001) Oceanic 18S rDNA sequences from picoplankton reveal unsuspected eukaryotic diversity. Nature 409:607-610

Platt T, Subba Rao DV, Irvin B (1983) Photosynthesis of picoplankton in the oligotrophic ocean. Nature 300:702-704

Reckerman M, Veldhuis MJW (1997) Trophic interactions between picophytoplankton and micro- and nanozooplankton in the western Arabian Sea during the NE monsoon 1993. Aquatic Microb Ecol 12:263-273

Rippka R, Coursin T, Hess WR, Lichtlé C and 6 others (2000) Prochlorococcus marinus Chisholm et al. 1992 subsp. pastoris subsp. nov, strain PCC 9511, the first axenic chlorophyll $a_{2} / b_{2}$-containing cyanobacterium (Oxyphotobacteria). Int J Syst Evol Microbiol 50:1833-1847

Sheldon RW, Prakash A, Sutcliffe WH (1972) The size distribution of particles in the ocean. Limnol Oceanogr 17:327-340

Sherr EB, Sherr BF, Paffenhöfer GA (1986) Phagotrophic protozoa as food for metazoans: a 'missing' trophic link in marine pelagic food webs? Mar Microb Food Webs 1: $61-80$

Sherr EB, Sherr BF, Fessenden L (1997) Heterotrophic protists in the Central Arctic Ocean. Deep-Sea Res II 44: $1665-1682$

Vaulot D (1989) CytoPC: Processing software for flow cytometric data. Signal Noise 2:8

Vaulot D, Marie D, Olson RJ, Chisholm SW (1995) Growth of Prochlorococcus, a photosynthetic prokaryote, in the equatorial Pacific Ocean. Science 268:1480-1482

Waterbury JB, Watson SW, Guillard RRL, Brand LE (1979) Widespread occurrence of a unicellular, marine planktonic, cyanobacterium. Nature 277:293-294

Wikner J, Hagström $\AA$ (1988) Evidence for tightly coupled nanoplanktonic predator-prey link regulating the bacterivores in the marine environment. Mar Ecol Prog Ser 50: $137-145$

Zohary T, Robarts RD (1992) Bacterial numbers, bacterial production, and heterotrophic nanoplankton abundance in a warm core eddy in the Eastern Mediterranean. Mar Ecol Prog Ser 84:133-137

Submitted: April 9, 2001; Accepted: September 25, 2001

Proofs received from author(s): November 7, 2001 